\title{
Comparison of Ohip-14 and Gohai Measures in Relation to Sociodemographic Factors in Older People
}

\section{OHIP-14 versus GOHAI measures}

\author{
Maria Vieira de Lima Saintrain ${ }^{1 *}$, Sandy Kaena Soares de Freitas ${ }^{2}$,
} Aldo Angelim Dias ${ }^{3}$, Lia Pinheiro Freitas ${ }^{4}$, Luciana Leite Pequeno

*1. DDS, Msc, PhD, Pos-doc in Public Health, Professor of the Public Health Masters Program,

University of Fortaleza - UNIFOR, Brazil.

2. Student of Dentistry Course - University of Fortaleza- UNIFOR, Brazil

3. DDs. PhD. Professor of Dentistry Course - University of Fortaleza - UNIFOR

4. Nurse. Student of the Public Health Master Program of the University of Fortaleza - UNIFOR

5. DDS, Msc. Student at the Public Health Doctorate Program - University of Fortaleza, UNIFOR, Brazil.

${ }^{1}$ mvlsaintrain@yahoo.com.br, ${ }^{2}$ sandy_kaena@hotmail.com, ${ }^{3}$ aldo_angelim@hotmail.com,

${ }^{4}$ liapinheiro22@gmail.com, ${ }^{5}$ luciannapequeno@gmail.com

\begin{abstract}
:
Objective: To compare the OHIP-14 and GOHAI measures in relation to sociodemographic factors in older people.

Methodology: Quantitative, descriptive and analytical cross-sectional research represented by the universe of older people aged 60 and over living in the municipality of Fortaleza - Ceará. We applied: a) a structured questionnaire on sociodemographic data (age, sex, race, marital status, education, occupation and income), general health (current health status and the comparison between current health and health in the past year, presence of systemic diseases), b) OHIP-14 (Oral Health Impact Profile), and c) GOHAI (Geriatric Oral Health Assessment Index). Results: In the analysis of the two questionnaires, OHIP and GOHAI, sociodemographic factors presented statistical significance regarding marital status ( $p=0.034$ and $p=0.017$, respectively) and race ( $p=0.035$ and $p=0.005$, respectively), with no statistical significance between the other variables. There was a strong relationship in the dispersion between the two measures $(p<0.001)$.
\end{abstract}

Conclusion: The results of the inferred variables indicate that the two indexes have the same assessment capacity and can be used as oral health indicators in the context of public health, serving as a social framework for the development of better public policies on the oral health of older people.

Descriptors: Quality of Life; Oral Health; Elder.

\section{INTRODUCTION}

The world population is experiencing an unprecedented age transition; because of that, the World Health Organization predicts that soon the world will have more older people than children and more people of very old age ${ }^{(1)}$.

The growth of the Brazilian elderly population - defined as people aged 60 and over ${ }^{(2)}-$ is becoming more significant as 650,000 new elderly people are incorporated into the population every year ${ }^{(3)}$.

This process of rapid and intense population aging indicates the need for developing a health policy designed to meet the needs of the older population ${ }^{(4)}$.

It is known that the longer the average life expectancy of the population, the more important it is the concept of quality of life, with oral health playing an important role within this context ${ }^{(5)}$.

In this context, the $2^{\text {nd }}$ National Conference on Oral Health ${ }^{(6)}$ considers "Oral health as an integral and inseparable part of an individual's general health". However, only the clinical assessment is not enough to know how patients perceive their oral health and what effect this condition has on their quality of life. 
Among the systems designed to answer these questions are the Oral Health Impact Profile - OHIP ${ }^{(7)}$, its short form - the OHIP-14 ${ }^{(8)}$, and the Geriatric Oral Health Assessment Index - GOHAI ${ }^{(9)}$, which contain important questions to assess the impact of oral health on quality of life considering physical, social and psychological aspects.

It is worth considering that Berkey, Call and Loupe ${ }^{(10)}$ have highlighted that self-reported symptoms, oral health status and perceived treatment needs are important and measurable dimensions of oral health-related quality of life. Therefore, a good oral health is essential to general health, well-being and quality of life, bringing significant benefits to self-esteem, dignity, social integration and nutrition in general.

When it comes to quality of life, one should take into account not only the physical health and the presence or absence of diseases, but also the implications of the social context in which individuals are embedded, being important to consider the psychological state, the level of independence, social relationships, environmental factors, and the personal beliefs ${ }^{(11)}$.

This study aimed to compare the OHIP-14 and GOHAI measures in relation to sociodemographic factors in older people.

\section{METHODS}

This is a quantitative, descriptive and analytical cross-sectional research conducted with elderly individuals living in the city of Fortaleza, capital of the State of Ceará, located in Northeastern Brazil. Older people are those aged 60 or above according to the National Policy for the Health of the Elderly People ${ }^{(2)}$.

The municipality of Fortaleza, in the state of Ceará, is divided into six Regional Executive Secretariats (Secretarias Executivas Regionais - SER), with a total of 93 Primary Health Centers (Unidades Básicas de Saúde-UBS). The research took place in two UBS of each region, which were selected at random.

Sample size was calculated using the 2012 data from DATASUS ${ }^{(12)}$ (the Brazilian Health System Database) on the total number of older inhabitants of the municipality of Fortaleza $(N=242,430)$. The minimum sample size was calculated based on an expected maximum proportion of $22 \%$, a significance level of 5\% and a maximum permissible error of 5\%. Thus, the sample size was 264 older people ${ }^{(13)}$. Older people from all health administrative regions of the city were investigated based on a sample stratified proportionally to the number of older people in each region.

The study was conducted using interviews, a) questionnaire on sociodemographic data (age, sex, race, marital status, education, occupation and income), general health (current health status and the comparison between current health status and health in the past year, presence of systemic diseases), b) OHIP-14 questionnaire (Oral Health Impact Profile), and c) GOHAI index (Geriatric Oral Health Assessment index).

The OHIP-14 consists of a questionnaire with 14 items with responses scoring $0-4$, where: never $=0$; rarely $=1$; sometimes $=2$; repeatedly $=3$; always $=4$. The GOHAI index consists of 12 multiplechoice questions about dental problems that assess three domains: physical, psychosocial and pain/discomfort.

For each question there are three possible answers: always; sometimes; and never - scoring 1, 2 and 3, respectively. The sum of all scores of each question comprises the index value for the individual, ranging from 12 to 36; these values are classified as: high (34 to 36), moderate (31 to 33) and low (less than or equal to 30$)^{(14)}$. The two indexes have the power to assess the oral health-related quality of life.

The researcher and the person taking notes were duly trained in order to standardize data collection.

Data were analyzed statistically using the Statistical Package for the Social Sciences Software (SPSS version 15, SPSS Co, Chicago, USA).

The descriptive and analytical analyses were performed according to the objectives of this study. For the analysis of the OHIP-14 and GOHAI indexes, data were initially tested for normality using Kolmogorov-Smirnov test. Normality was not present in both indexes $(p<0.001)$. To facilitate understanding, the GOHAI scale was reversed so that the higher the value of the sum of the scores, the lower the quality of life of respondents, which allowed a direct comparison of the two indexes. 
Inferences about both indexes were made based on the mean value of its scores, considering statistically significant the inferential analyses with $\mathrm{p}$-value below $0.05(\mathrm{p}<0.05)$.

To determine the existence of significant differences between the groups of the dependent variable, the Mann-Whitney U Test was used to compare two categories and the Kruskal-Wallis Test for more than two categories. The Spearman's Correlation Coefficient was also used.

The study inclusion criteria were people aged 60 and over who were aware of the Free Informed Consent Form and agreed to participate.

The study protocol complied with the ethical principles of autonomy, non-maleficence, beneficence and justice in research involving human beings, as stated in Resolution No. 466/12 of the National Health Council, and was approved by the Research Ethics Committee of the University of Fortaleza UNIFOR under the No. 745.659/2014.

\section{Results}

In all, 264 older people aged 60-88 years, mean age of 68.5 ( $\mathrm{SD} \pm 6.8$ years), were interviewed in the period from July to September 2015.

With regard to sociodemographic data, the sample was predominantly: female [187 (70.8\%)], married [120 (45.5\%)], had an income of one minimum wage [194 (73.5\%)], incomplete primary education [124 (47\%)], uneducated [54 (20.5\%)], and retired [179 (67.8\%)]. (Table 1).

Regarding self-reported health, 209 (79.2\%) of the respondents rated their health as excellent or fair, $81(30.7 \%)$ considered their health better than it was in the past year, and $224(84.8 \%)$ had systemic diseases, including Diabetes mellitus (45.5\%), hypertension (62.1\%) and osteoporosis (27.3\%). (Table 2).

The comparison of the oral health-related quality of life measured by the OHIP-14 and the GOHAI took into consideration the median and the mean plus the standard deviation. Thus, with regard to sociodemographic factors, statistical significance was found for marital status ( $\mathrm{p}=0.034$ and $\mathrm{p}=0.017$, respectively) and race ( $\mathrm{p}=0.035$ and $\mathrm{p}=0.005$, respectively), with no statistical significance between the other variables. (Table 3 ).

As for the degree of dispersion, there was a correlation of $76.3 \%$, indicating a strong relationship between the two measures that could be confirmed by the significance test $(\mathrm{p}<0.001)$. (Graph 1).

The results shown in Table 1 identify the frequency distribution of sociodemographic data on older people.

Table 2 shows the frequency distribution of data on the general health of older people.

Table 3 shows the results of the comparative analysis of the sociodemographic data of the older people and the median of the OHIP-14 versus GOHAI.

Graph 1 shows the degree of dispersion between the OHIP-14 versus GOHAI. The Spearman's Correlation Coefficient showed a strong relationship between the two measures $(\mathrm{p}<0.001)$.

Table1. Frequency distribution of sociodemographic data on older people. $($ N=264). Fortaleza-Ceará, 2015

\begin{tabular}{|l|c|c|}
\hline Variables & $\mathrm{n}$ & $\%$ \\
\hline $\begin{array}{l}\text { Age group } \\
\text { 60-69 years }\end{array}$ & 160 & 60.6 \\
\hline 70-79 years & 77 & 29.2 \\
\hline $80-88$ years & 27 & 10.2 \\
\hline Gender & 187 & 70.8 \\
Female & 77 & 29.2 \\
\hline Male & & \\
\hline Marital status & 64 & 24.2 \\
Single & 120 & 45.5 \\
\hline Married & 28 & 10.6 \\
\hline Divorced & 52 & 19.7 \\
\hline Widowed & 149 & 56.4 \\
\hline Race & 51 & 19.3 \\
White & 61 & 23.1 \\
\hline Black & & \\
\hline Brown & & \\
\hline
\end{tabular}


Maria Vieira de Lima Saintrain et al.

\begin{tabular}{|l|c|c|}
\hline \hline Other & 3 & 1.1 \\
\hline Retired & 179 & 67.8 \\
Yes & 85 & 32.2 \\
\hline No & & 29.5 \\
\hline Employed & 78 & 70.5 \\
Yes & 186 & \\
No & 194 & 73.5 \\
\hline Income & 68 & 25.8 \\
1 wage & 2 & 0.8 \\
\hline $2-5$ wages & & \\
\hline 5 wages or more & 54 & 20.5 \\
\hline Education & 124 & 47.0 \\
None & 40 & 15.2 \\
\hline Incomplete primary education & 11 & 4.2 \\
\hline Complete primary education & 32 & 12.1 \\
\hline Incomplete secondary education & 3 & 1.1 \\
\hline Complete secondary education & & \\
Higher education & & \\
\hline
\end{tabular}

Source: research data

Table2. Frequency distribution of data on the general health of older people. (N=264). Fortaleza-Ceará, 2015

\begin{tabular}{|c|c|c|}
\hline Variables & $\mathrm{n}$ & $\%$ \\
\hline $\begin{array}{l}\text { Current health } \\
\text { Excellent }\end{array}$ & 63 & 23.9 \\
\hline Fair & 146 & 55.3 \\
\hline Poor & 54 & 20.5 \\
\hline $\begin{array}{l}\text { Health in the past year } \\
\text { Better }\end{array}$ & 81 & 30.7 \\
\hline $\begin{array}{l}\text { The same } \\
\text { Worse }\end{array}$ & $\begin{array}{c}124 \\
59\end{array}$ & $\begin{array}{c}47 \\
22.3 \\
\end{array}$ \\
\hline $\begin{array}{l}\text { Systemic diseases } \\
\text { Yes }\end{array}$ & 224 & 84.8 \\
\hline No & 40 & 15.2 \\
\hline $\begin{array}{l}\text { Diabetes mellitus } \\
\text { Yes }\end{array}$ & 120 & 45.5 \\
\hline No & 144 & 54.4 \\
\hline $\begin{array}{l}\text { Hypertension } \\
\text { Yes }\end{array}$ & 164 & 62.1 \\
\hline No & 100 & 37.9 \\
\hline $\begin{array}{l}\text { Osteoporosis } \\
\text { Yes } \\
\text { No }\end{array}$ & $\begin{array}{c}72 \\
192\end{array}$ & $\begin{array}{l}27.3 \\
72.7\end{array}$ \\
\hline $\begin{array}{l}\text { Cancer } \\
\text { Yes }\end{array}$ & 9 & 3.4 \\
\hline No & 255 & 96.6 \\
\hline $\begin{array}{l}\text { Rheumatism } \\
\text { Yes }\end{array}$ & 27 & 10.2 \\
\hline No & 237 & 89.8 \\
\hline AIDS & & \\
\hline Yes & 2 & 0.8 \\
\hline No & 262 & 99.2 \\
\hline Tuberculosis & & \\
\hline Yes & 1 & 0.4 \\
\hline No & 263 & 99.6 \\
\hline Hansen's disease & & \\
\hline Yes & 2 & 0.8 \\
\hline No & 262 & 99.2 \\
\hline Nephritis & & \\
\hline Yes & 1 & 0.4 \\
\hline No & 263 & 99.6 \\
\hline
\end{tabular}

Source: research data 
Comparison of Ohip-14 and Gohai Measures in Relation to Sociodemographic Factors in Older People

Table3. Comparative analysis of the sociodemographic data of the older people and the median of the OHIP-14 versus GOHAI. Fortaleza-Ceará, 2015

\begin{tabular}{|c|c|c|c|c|c|c|c|}
\hline \multirow[b]{2}{*}{ Variables } & \multirow[b]{2}{*}{$\mathrm{n}$} & \multicolumn{2}{|c|}{ OHIP-14 } & \multirow[b]{2}{*}{$\mathrm{p}$} & \multicolumn{2}{|c|}{ GOHAI } & \multirow[b]{2}{*}{$\mathrm{p}$} \\
\hline & & Median & Mean+SD & & Median & Mean+SD & \\
\hline $\begin{array}{l}\text { Age group } \\
60-69 \text { years }\end{array}$ & 160 & 12 & $13.8 \pm 10.1$ & & 31 & $17.6 \pm 4.5$ & \\
\hline $70-79$ years & 77 & 12 & $15.4 \pm 11.9$ & $0.799 * *$ & 30 & $17.8 \pm 4.4$ & $0.577 * *$ \\
\hline $80-88$ years & 27 & 10 & $15.7 \pm 14.6$ & & 30 & $18.7 \pm 5.1$ & \\
\hline $\begin{array}{l}\text { Gender } \\
\text { Female }\end{array}$ & 187 & 12 & $14.2 \pm 11.1$ & $0.622 *$ & 31 & $17.8 \pm 4.3$ & $0.703 *$ \\
\hline Male & 77 & 12 & $15 \pm 11.4$ & & 31 & $17.8 \pm 5$ & \\
\hline $\begin{array}{l}\text { Marital status } \\
\text { Single }\end{array}$ & 64 & 10.5 & $13.8 \pm 11.1$ & & 31 & $17.6 \pm 4.5$ & \\
\hline Married & 120 & 11 & $12.8 \pm 10.3$ & $0.034 * *$ & 32 & $17 \pm 4.2$ & $0.017 * *$ \\
\hline Divorced & 28 & 14 & $15 \pm 9.3$ & & 30 & $18.7 \pm 4.7$ & \\
\hline Widowed & 52 & 14 & $18.8 \pm 13.1$ & & 29 & $19.3 \pm 4.8$ & \\
\hline $\begin{array}{l}\text { Skin color } \\
\text { White }\end{array}$ & 149 & 11 & $13.2 \pm 10.7$ & $0.035 *$ & 32 & $17.2 \pm 4.5$ & $0.005^{*}$ \\
\hline Non-white & 115 & 14 & $16.1 \pm 11.6$ & & 29 & $18.6 \pm 4.4$ & \\
\hline $\begin{array}{l}\text { Retired } \\
\text { Yes }\end{array}$ & 179 & 12 & $14.5 \pm 12$ & $0.466^{*}$ & 31 & $17.8 \pm 4.8$ & $0.500 *$ \\
\hline No & 85 & 12 & $14.5 \pm 9.3$ & & 31 & $17.8 \pm 3.8$ & \\
\hline $\begin{array}{l}\text { Income } \\
1 \text { wage }\end{array}$ & 194 & 11 & $14.1 \pm 10.8$ & & 31 & $17.8 \pm 4.4$ & \\
\hline $\begin{array}{l}2-5 \text { wages } \\
5 \text { wages or more }\end{array}$ & $\begin{array}{c}68 \\
2 \\
\end{array}$ & $\begin{array}{l}12 \\
11\end{array}$ & $\begin{array}{c}15.5 \pm 12.5 \\
11 \pm 1.4\end{array}$ & $0.842 * *$ & $\begin{array}{c}31 \\
30.5\end{array}$ & $\begin{array}{l}17.7 \pm 4.8 \\
17.5 \pm 6.4\end{array}$ & $0.923 * *$ \\
\hline $\begin{array}{l}\text { Education } \\
\text { None }\end{array}$ & 54 & 13 & $15.7 \pm 10.2$ & & 31 & $18.3 \pm 4.5$ & \\
\hline $\begin{array}{l}\text { Incomplete primary } \\
\text { education }\end{array}$ & 124 & 12 & $15.4 \pm 11.9$ & & 31 & $18 \pm 4.7$ & \\
\hline $\begin{array}{l}\text { Complete primary } \\
\text { education }\end{array}$ & 40 & 9 & $12.4 \pm 12.4$ & $0.274 * *$ & 32 & $16.7 \pm 4.5$ & $0.473 * *$ \\
\hline $\begin{array}{l}\text { Incomplete } \\
\text { secondary education }\end{array}$ & 11 & 14 & $13.1 \pm 5.4$ & & 30 & $17.6 \pm 3.4$ & \\
\hline $\begin{array}{l}\text { Complete secondary } \\
\text { education }\end{array}$ & 32 & 9 & $12.5 \pm 9.9$ & & 31.5 & $17.7 \pm 4.4$ & \\
\hline Higher education & 3 & 9 & $8 \pm 3.6$ & & 33 & $15.3 \pm 2.5$ & \\
\hline
\end{tabular}

Research data: * Mann-Whitney U Test; ** Kruskal-Wallis Test.

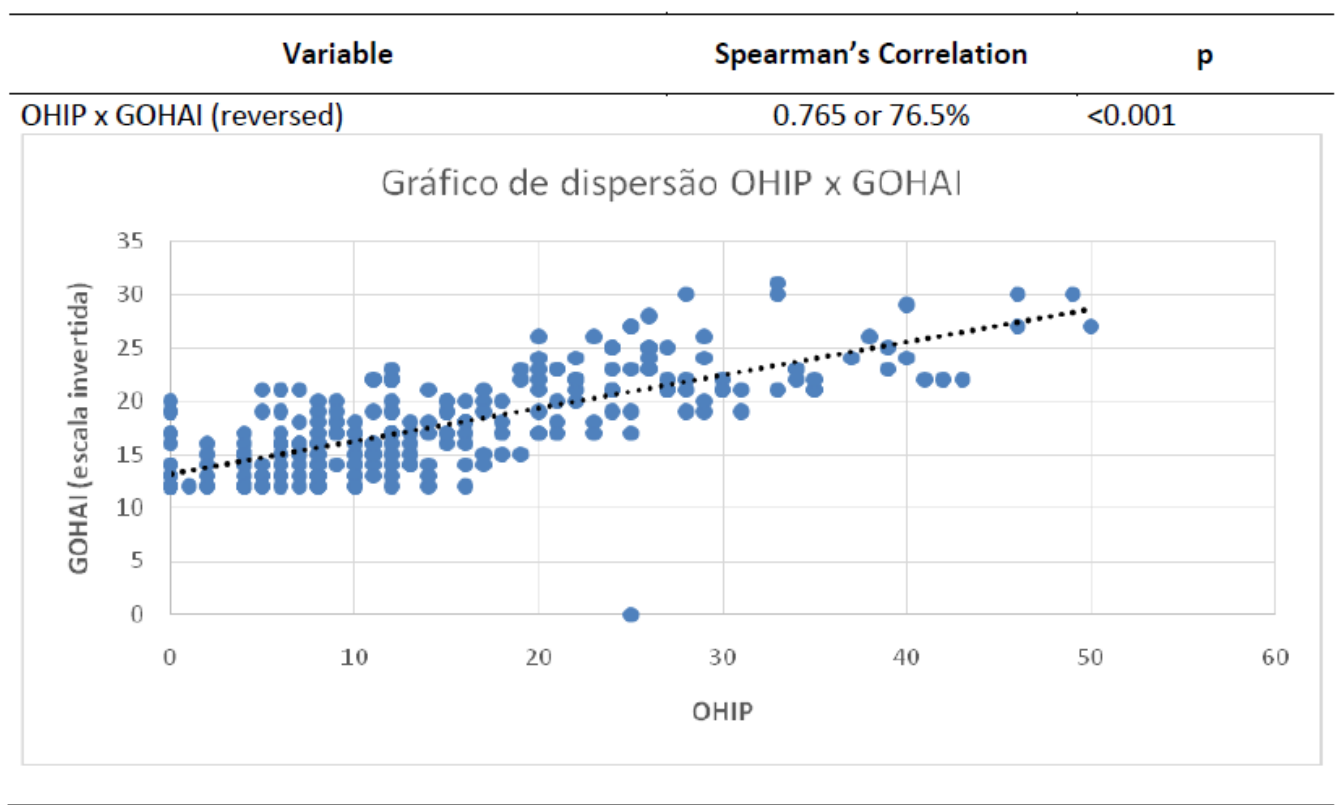

Graph1. Dispersion of OHIP-14 versus GOHAI 


\section{DisCUSSION}

The subjective evaluation of quality of life refers to what people think and how they feel about their lives ${ }^{(15)}$.

Based on this concept, we sought to compare the results related to the quality of life of older people using the OHIP-14 and the GOHAI taking into consideration sociodemographic factors. The authors of the present research believe that this is a unique study due to the lack of comparative analyses to simultaneously assess these indexes and their relationship to sociodemographic variables of older people.

The characterization of the sample revealed a predominance of women $(70.8 \%)$, a result that is similar to that observed in other studies ${ }^{(16,17,18,19)}$. This fact may be explained by the longer life expectancy of women, which highlights the feminization of old age ${ }^{(20)}$. In addition, there is an increased frequency and participation of women in primary health centers - the locale where the present research took place.

The fact that older people had "no or low education" (67.5\%) is supported by an epidemiological survey on oral health carried out in Brazil by the Ministry of Health, in which $35 \%$ of the older people were illiterate and $44.2 \%$ had less than four years of education ${ }^{(21)}$.

In addition, the majority of the respondents (73.5\%) reported having a low income, revealing a population with scarce educational and financial resources. In the analysis of income and education, the median values were similar in the two instruments, suggesting the same assessment capacity of both indexes.

In this context, Sanders, Slade, Lim and Reisine ${ }^{(22)}$, who assessed the OHIP-14 scores in the US and Australian population, considered the magnitude of the effect of income. They found a significant difference $(\mathrm{p}<0.005)$ between people with the lowest income and those with the highest income in the two populations, respectively.

As for self-reported health, although the majority $(84.8 \%)$ of the older people presented systemic diseases, $79.2 \%$ rated their health as excellent or fair and 30\% reported their health was better than it was in the past year. The fact that older people have different systemic diseases does not mean they have a poor health.

Provided that there is a balanced control of diseases, these people may feel healthy. The same applies to oral health. According to some studies, older people have a good self-perception ${ }^{(14,23)}$ and a positive self-evaluation of their oral health status ${ }^{(24,25)}$ even when, in most cases, their clinical condition is not satisfactory. This indicates that a poor oral health is being considered something "natural" by older people ${ }^{(26)}$, highlighting a cultural attitude of resignation in the face of old age that leads one to believe that the presence of disease is part of the aging process.

Older patients with these pathological conditions usually use a large amount of medications, which can influence the decrease of saliva. This fact, in most cases, generates harmful events such as lack of taste and dry mouth, leading to oral discomfort ${ }^{(27,28)}$.

All these aspects may have an impact on the quality of life as life satisfaction - determined by the physical, social and psychological satisfaction, gender, age, socioeconomic status, educational level, among others - is recognized as a strong indicator of quality of life ${ }^{(29)}$.

Studies comparing the GOHAI and OHIP-14 have been conducted with older people living in Canada, Japan, Poland, Germany and Lebanon ${ }^{(19,30,31,32,33)}$. However, none of them aimed to relate the scores of the indexes to the sociodemographic conditions of the population studied.

Although some studies have correlated variables such as gender, education and income of participants, their main objective has been to compare the OHIP-14 and the GOHAI in terms of oral health in order to identify the best oral health indicator for the older population.

Most $(60 \%)$ of these studies highlight that the GOHAI is more accurate to assess the oral healthrelated quality of life of older people, although both indexes present similar results ${ }^{(19,30,31)}$.

Noteworthy, the satisfaction with oral health is influenced by the respondent's memory, physical and psychological characteristics, and contextual and cultural aspects of each population group ${ }^{(34)}$, standing out as important contextual variables to be investigated; however, some authors report that little is known about the effects of these variables ${ }^{(35,36)}$. 
The social context is considered a potential determinant of the attitudes of individuals. However, one cannot generalize a single perception of oral health to all the people inserted in the same social, economic and cultural context, for there are individual variables that appear to be more relevant to research on perceived oral health ${ }^{(37)}$.

In the present study, when analyzing the comparative relationship between sociodemographic conditions and the OHIP-14 and GOHAI indexes, the variables marital status and race were statistically significant in both indexes, showing, therefore, the same assessment capacity. Additionally, no significance was found in other variables in both indexes, reinforcing its power of equality, which is well analyzed by the dispersion graph obtained by the Spearman's Correlation test.

The fact that the research universe is focused on a single municipality stands out as one limitation of the present study, which prevents the extrapolation of results.

However, because it is a large municipality in Brazil, it is expected that the findings are also true elsewhere, showing that both the OHIP-14 and the GOHAI have the capacity to measure the impact of socioeconomic status on oral diseases and quality of life of older people. Also, the findings may form the basis of equity in public health care policies. Further studies should improve research in this area.

Given the above, it is possible to point out that although the GOHAI is specifically used to assess older people and the OHIP-14 can be used for all ages, this research demonstrated that both have the same capacity to assess the oral health-related quality of life of older people when related to sociodemographic conditions.

\section{Conclusion}

The comparative analysis of the OHIP-14 and the GOHAI with sociodemographic factors revealed that both questionnaires have the same capacity to assess the self-reported oral health-related quality of life of older people.

The measures obtained in the two indexes indicate that both can similarly assess the relationships between sociodemographic variables and quality of life, pointing out significant relationships in the same comparisons, confirming these indexes as oral health indicators in research in the context of public health, serving as a social framework for the development of better public policies on the oral health of the older population.

\section{Author Contributions}

Freitas SKS, MV L Saintrain and LL Pequeno devised the research project, performed data collection, literature review, and analysis, wrote the first draft of the article and final revision. Dias AA and Freitas LP performed data analysis and literature review, and contributed to the final version of the article.

\section{REFERENCES}

[1] World Health Organization. Global Health and Aging. National Institute on Aging. National Institutes of Health. NIH Publication no. 11-7737. October, 2011.

[2] Brasil. Ministério da Saúde. Portaria $n^{\circ}$ 2528, de 19 de outubro de 2006. Aprova a Política Nacional de Saúde da Pessoa Idosa. Diário Oficial da República Federativa do Brasil. 2006. Out. 20; Seção 1, p. 142

[3] Veras R. Envelhecimento populacional contemporâneo: demandas, desafios e inovações. Rev Saúde Pública 2009;43(3):548-54.

[4] Bianco VC, Lopes ES, Borgato MH, Silva PM, Marta SN. O impacto das condições bucais na qualidade de vida de pessoas com cinquenta ou mais anos de vida. Cien Saude Colet 2010;15(4):2165-2172.

[5] Barbosa AF, Barbosa AB. Odontologia Geriátrica - Perspectivas atuais. J Bras Cli Odont Integ 2002;6(33);231-34.

[6] Ministério da Saúde. Relatório final da $2^{\text {a }}$ Conferência Nacional de Saúde Bucal. Brasília: Conselho Nacional de Saúde; 1993.

[7] Slade GD. Development and evaluation of the Oral Health Impact Profile. Community Dent Health 1994; 11(1):3-11.

[8] Slade GD. Derivation and validation of a short form Oral Health Impact Profile. Community Dental Oral Epid 1997; 25:284-90. 
[9] Atchison KA, Dolan TA. Development of the geriatric oral health assessment index. J Dent Educ 1990; 54:680-687.

[10] Berkey DB, Call RL, Loupe MJ. Oral health perceptions and self-esteem in non-institutionalized older adults. Gerodontics 1987; 3:109-112.

[11] Silva SRC, Junior AV. Avaliação das condições de saúde bucal dos idosos em um município brasileiro. Rev Panam Salud Publica/Pan Am J Public Health 2000; 8(4):268-271.

[12] Datasus. Informações de Saúde. População residente por faixa etária, segundo Município. Período 2012. [Accessed on 09 Jan 2015] Available at: http://tabnet.datasus.gov.br/cgi/ tabcgi.exe?idb2012/a01.def.

[13] Santos GEO. Cálculo amostral: calculadora on-line. [Accessed on 09 Jan 2014]. Available at: http://www.calculoamostral.vai.la

[14] Silva DD, Sousa MLR, Wada RS. Autopercepção e condições de saúde bucal em uma população de idosos. Cad Saúde Pública 2005; 21(4):1251-1259.

[15] Giacomoni CH. Bem-estar subjetivo infantil: conceito de felicidade e construção de instrumentos para avaliação [Tese de doutorado]. Porto Alegre: Universidade Federal do Rio Grande do Sul; 2002.

[16] Agostinho ACMG, Campos ML, Silveira JLGC. Edentulismo, uso de prótese e autopercepção de saúde bucal entre idosos. Rev Odontol UNESP 2015; 44(2):74-79.

[17] Moura C, Cavalcante FT, Catão MHCV, Gusmão ES, Soares RSC, Santillo PMH. Fatores relacionados ao impacto das condições de saúde bucal na vida diária de idosos, Campina Grande, Paraíba, Brasil. Pesq Bras Odontoped Clin Integr 2011; 11(4):553-559.

[18] Souza EHA, Barbosa MBCB, Oliveira PAP, Espíndola, J, Gonçalves KJ. Impacto da saúde bucal no cotidiano de idosos institucionalizados e não institucionalizados da cidade do Recife (PE, Brasil). Cien Saude Colet 2010; 15(6):2955-2964.

[19] Osta NE, Tubert-Jeannin S, Hennequin M, Naaman NBA, Osta LE, Geahchan N. Comparison of the OHIP-14 and GOHAI as measures of oral health among elderly in Lebanon. Health Qual Life Outcomes 2012; 10:131.

[20] Salgado CDS. Mulher idosa: a feminização da velhice. Estud interdiscip envelhec Porto Alegre. 2002; 4:7-19.

[21] Ministério da Saúde. Projeto SB Brasil: Condições de saúde bucal da população brasileira 20022003: resultados principais. Brasília: Coordenação Nacional de Saúde Bucal; 2004.

[22] Sanders AE, Slade GD, Lim S, Reisine ST. Impact of oral disease on quality of life in the US and Australian populations. Community Dent Oral Epidemiol 2009; 37(2):171-181.

[23] Haikal DS, Paula AMB, Martins AMEBL, Moreira AN, Ferreira EF. Autopercepção da saúde bucal e impacto na qualidade de vida do idoso: uma abordagem quanti-qualitativa. Cienc Saúde Coletiva 2011; 16:3317-3329.

[24] Locker D, Clarke M, Payne B. Self perceived oral health status, psychological well-being, and life satisfaction in an older population. J Dent Res 2000; 79:970-975.

[25] Martins AMEBL, Barreto SM, Pordeus IA. Auto-avaliação de saúde bucal em idosos: análise com base em modelo multidimensional. Cad Saude Pública 2009; 25:421-435.

[26] Costa EHM, Saintrain MVL, Vieira APGF. Autopercepção da condição de saúde bucal em idosos institucionalizados e não institucionalizados. Cienc Saude Coletiva 2010; 15(6):29252930.

[27] World Health Organization. Global status report on noncommunicable diseases 2010. Geneva; 2011.

[28] Saintrain MVL, Gonçalves RD. Salivary tests associated with people's oral health. Gerodontology. 2013; 30:91-97.

[29] Fleck MPA. O instrumento de avaliação de qualidade de vida da Organização Mundial da Saúde (WHOQOL-100): características e perspectivas. Cien Saude Colet. 2000; 5(12):33-38.

[30] Locker D, Matear D, Stephens M, Lawrence H, Payne B. Comparison of the GOHAI and OHIP14 as measures of the oral health-related quality of life of the elderly. Community Dent Oral Epidemiol 2001; 29:373-381. 
[31] Ikebe K, Hazeyama T, Enoki K, Murai S, Okada T, Kagawa R, et al. Comparison of GOHAI and OHIP-14 measures in relation to objective values of oral function in elderly Japanese. Community Dent Oral Epidemiol 2012; 40:406-414.

[32] Rodakowska E, Mierzyńska K, Bagińska, J, Jamiołkowski J. Quality of life measured by OHIP14 and GOHAI in elderly people from Bialystok, north-east Poland. BMC Oral Health 2014; 14:106-114.

[33] Hassel AJ, Steuker B, Rolko C, Keller L, Rammelsberg P, Nitschke I. Oral health-related quality of life of elderly Germans--comparison of GOHAI and OHIP-14. Community Dent Health 2010; 27(4):242-247.

[34] Campos ACV, Vargas AMD, Ferreira EF. Satisfação com saúde bucal de idosos brasileiros: um estudo de gênero com modelo hierárquico. Cad Saude Publica. 2014; 30(4):757-773.

[35] Antunes JL, Narvai PC, Nugent ZJ. Measuring inequalities in the distribution of dental caries. Community Dent Oral Epidemiol 2004; 32(1):41-48.

[36] Pattussi MP, Marcenes W, Croucher R, Sheiham A. Social deprivation, income inequality, social cohesion and dental caries in Brazilian school children. Soc Sci Med 2001; 53(7):915-925.

[37] Tassanari WS, León AP, Werneck GL, Faerstein E, Lopes CS, Chor D, et al. Contexto sócioeconômico e percepção da saúde bucal em uma população de adultos no Rio de Janeiro, Brasil: uma análise multinível. Cad. Saúde Pública. 2007; 23(1):127-136. 